Article

\title{
The Populist Radical Right in the US: New Media and the 2018 Arizona Senate Primary
}

\author{
Jeremy C. Roberts \\ Department of Political Science, Western University, London, N6A 3K7, Canada; E-Mail: jrobe65@uwo.ca
}

Submitted: 29 September 2019 | Accepted: 23 January 2020 | Published: 5 March 2020

\begin{abstract}
This article analyzes the appeal of populist radical right (PRR) politics in the US after the election of Donald Trump. Specifically, I seek to explain how new media helps politicians representing the PRR secure support in Republican primaries. Using an online survey of 1052 Arizona Republicans in the lead-up to the August 2018 Senate primary, I evaluate support for three candidates: Rep. Martha McSally, former Maricopa County Sheriff Joe Arpaio, and Kelli Ward, a physician. The findings highlight a bifurcation in the drivers for support of PRR candidacies: Skepticism of immigration drives the Arpaio vote, while use of social media news and belief in party convergence mobilize Ward's support. The results demonstrate that support for PRR politicians in the Arizona primary is concentrated in two groups, anti-immigrant and anti-establishment, and that the anti-establishment voters are more likely to access news on social media. These findings indicate that social media news consumption does shape voter perceptions about mainstream parties favorably for the PRR.
\end{abstract}

\section{Keywords}

convergence; Donald Trump; new media; populism; populist radical right

\section{Issue}

This article is part of the issue "Leadership, Populism and Power" edited by Cristine de Clercy (Western University, Canada).

(C) 2020 by the author; licensee Cogitatio (Lisbon, Portugal). This article is licensed under a Creative Commons Attribution 4.0 International License (CC BY).

\section{Introduction}

In 2016, Donald Trump shocked observers by winning the Republican nomination and the presidency. Trump, a politically inexperienced real estate developer, reality television star, and conservative commentator, was hardly a favored candidate. He spewed anti-elite invectives, rejected the Republican establishment, and challenged Republican doctrine on issues like immigration and trade. Trump's unorthodox policies, charisma, and media profile set him apart as a different breed of Republican. Party loyalty, combined with an uninspiring Democratic alternative in Hillary Clinton, may help explain Trump's general election victory, but neither of these factors can explain how he bested his Republican competitors to win the party's nomination. Nor can they explain the success of Trump-like candidates in primaries around the country.

Some answers may lie in Europe. Trump is not a traditional Republican, but he does share ideological predilec- tions with European right-wing populists. While some scholarship has explored the transatlantic right, comparisons between the US and Europe often underemphasize the particularities of the US party system, and the importance of radical right actors mobilizing through a mainstream conservative party (Mudde, 2017, p. 51). Scholars seeking to explain the American radical right's recent surge have not taken advantage of the insights from across the Atlantic (Mudde, 2019, p. 97). This article bridges these gaps while building on recent literature on the social media's role in American elections.

In the wake of Trump's victory, pitched battles for the Republican Party's soul broke out in primaries across the country. I argue that Trump and post-Trump candidates represent an American incarnation of what Mudde (2007) calls the "populist radical right" (PRR), which emphasizes populism, nativism, and authoritarianism in its appeals. I explore party convergence as a necessary precondition for PRR success, per Kitschelt and McGann $(1995$, p. 17), and consider the role of new media in rela- 
tion to two hypotheses: (1) the PRR should be attractive to voters who believe the major parties have converged; and (2) PRR voters should be more likely to get their news from social media sources. I test these hypotheses using a survey of Arizona Republicans conducted before the 2018 Senate primary-the first electoral cycle of the Trump era. I find that PRR voters are more likely to perceive convergence between the mainstream party establishments and to use social media for news, but that this only holds for the candidate that emphasized anti-establishment rhetoric. In Arizona, the most credible anti-immigrant voice was more likely to attract voters concerned about the economic impact of immigration, lending support to demand side theories of PRR success.

\subsection{Defining the $P R R$}

What do we mean by "populist radical right"? The "radical" label denotes hostility to elements of liberal democracy, such as institutional pluralism and safeguards for minority rights (Plattner, 2010, p. 84). Populists invoke the "general will" and view politics as a conflict between the "pure people" and the "corrupt elite" (Mudde, 2007, p. 23). Mudde's (2007) term, PRR, which comprises actors that are populist, nativist, and authoritarian, accurately describes the Trump and post-Trump political phenomena in the US, and meets definitional requirements of analytical utility and cross-contextual portability.

PRR appeals border on anti-liberal democratic: Both American and European populists exhibit contempt for the independent judiciary. Donald Trump has been criticized for his attacks on a judge overseeing a lawsuit against him, for pardoning former Maricopa County Sheriff Joe Arpaio in a contempt of court case, and for the 2016 Republican platform, which called for the impeachment of activist judges (Peabody, 2018, pp. 243-245). In appealing to their own definition of "the people" as opposed to liberal democratic institutions, these figures are populist.

The PRR is nativist, advocating exclusionary nationalism. Trump's racially-charged comments about immigrants, along with his "Muslim ban," push him firmly into nativist territory. European PRR parties have also stoked anti-immigrant sentiment. According to Ellinas (2010, p. 12), "[t]he glue that ties these parties together is their shared understanding that the political should be congruent with the national." Finally, authoritarian appeals - those that emphasize conformity, deference, skepticism, and aggression in defense of those valuesfurther distinguish the PRR. Authoritarian candidacies tend to focus on immigration, law and order, and the military (Knuckey \& Hassan, 2019, pp. 2-3).

\subsection{Explanations for the Success of the PRR}

Explanations for PRR success fall into two main categories: supply side and demand side (Golder, 2016, p. 482). Demand siders suggest that so-called "losers of modernization," voters who feel left behind by globalization and the postindustrial economy, may find the PRR appealing (Betz, 1993; Kitschelt \& McGann, 1995, pp. 56, 275). The PRR's electorate is less-educated, more likely to be unemployed, and more likely to work in blue collar occupations (Imerzeel \& Pickup, 2015, p. 358). Macroeconomic factors are also important. Voters who are economically anxious and fear immigrant labor competition have reason to vote for the PRR. Jackman and Volpert (1996, pp. 516-517) highlight unemployment as a key explanatory variable, providing "the pretext for mounting the xenophobic political appeals that characterize these political movements." Overall, however, support for unemployment as an explanatory variable is mixed (Coffé, Heyndels, \& Vermier, 2007, p. 144; Golder, 2016, p. 484; Knigge, 1998, p. 266; Lubbers \& Scheepers, 2001, p. 443).

Cultural explanations, Golder's third demand side category, matter as well. These arguments hold that PRR support can be explained by cultural change brought about by mass immigration. To test this proposition, scholars have compared PRR success to immigration levels. Results are mixed (Coffé et al., 2007, p. 149; Golder, 2016, p. 485). Lubbers and Scheepers (2001, p. 443) find that extreme right support increased in Germany in regions where more asylum seekers settled, while Knigge (1998, p. 70) finds that "heightened levels of immigration...are conducive to the electoral success of extreme right-wing parties." Mudde (2007, pp. 212-216) provides a good overview of the literature. Other scholars offer versions of the cultural backlash thesis, arguing that the radical right succeeds where voters push back against concessions for minorities (Bustikova, 2014, pp. 1757-1758), or where intergenerational transitions in values create a cultural backlash among older voters (Norris \& Inglehart, 2019).

Supply side explanations for PRR success have become more common in recent years, as demand side explanations have consistently failed to explain results across different countries (Golder, 2016, p. 486). Supply siders hold that the key to a PRR party's success lies within the party itself. Explanatory factors include administrative competence and party organization (DeClair, 1999, p. 189; Ellinas, 2013, p. 561), leadership charisma (Art, 2011, p. 8), and favorable opportunity structures, including effective number of parties (Jackman \& Volpert, 1996) and convergence of left and right parties (Kitschelt \& McGann, 1995, pp. 58, 72).

Ideology is another factor: Scholars have evaluated the extent to which policy programs appeal to PRR voters. The most famous of these explanations is the "winning formula" (Kitschelt \& McGann, 1995), which holds essentially that PRR parties succeed when they combine authoritarian appeals with neoliberal economics (see also de Lange, 2007, pp. 429-430). Muis and Scholte (2013, p. 42) invoke ideological flexibility-that is, a shift to the economic left-in explaining the Dutch Party for Freedom's spike in electoral success. Harteveld (2016, 
p. 226) analyzed ten radical right parties, and found that a shift to the economic left attracts more working-class votes at the expense of the highly-educated and highlyskilled-demonstrating that economic policy programs do explain at least some party appeal.

Other supply side explanations focus on the media's role in facilitating PRR success (Boomgaarden \& Vliegenthart, 2007, p. 413; Ellinas, 2010). The PRR and the media have a symbiotic relationship: controversial policy positions help media outlets generate compelling content, while media attention helps the PRR build credibility with voters (Golder, 2016, p. 488). As the media landscape changes, new media, including Internet-based social media, has factored into analyses of PRR success. Stockemer and Barisione (2017, p. 111) find that social media activism contributed in part to gains the French National Front saw in the early 2010s, while Karl (2017, p. 353), draws a similar conclusion about Hungary's Jobbik.

This review provides a list of variables to be considered as part of an explanation for PRR success in the US. It remains necessary, however, to consider how insights drawn from the European literature apply in the American context. Arguably, the most important differences rest in the respective party systems. In the US, the Republicans and Democrats dominate political competition. Representatives of the PRR must compete against fellow right-leaning candidates in Republican primaries. Consequently, in the US, intra-party competition is the crucial battleground for the PRR, unlike in much of Europe, where proportional electoral systems facilitate diverse party systems.

Literature on the radical right in the US has neglected Republican intra-party competition and mobilization (Mudde, 2017, p. 51). In intra-party competitions, the key actors are individual candidates who only have the relatively short primary campaign to declare, articulate, and defend their ideological programs against criticism from fellow conservatives. Ideological positions are still important-libertarians, religious conservatives, and neoconservatives all compete in primaries-but differentiation can come down to effective messaging. In a fastpaced primary campaign where voters cannot rely on party cues (all candidates compete for the same party's nomination) and candidates may not have much name recognition (particularly in primaries for lower offices), the role of the media and information about candidates becomes especially important, as scholars have articulated in reference to the European example.

Of special importance is the relationship between social media and support for the PRR. While this literature is relatively underdeveloped in the European context, the details of the 2016 election have inspired some American literature. For example, Gunn (2017, p. 59) claims that "without Twitter or an equivalent social media platform, it would have been difficult for a candidate like Trump...to come across as viable." Groshek and Koc-Michalska (2017, p. 1402) find that social media were a critical part of Trump's 2016 victory, along with several other factors (including "television reliance" and "passive and uncivil social media users"). New mediaparticularly social media-offers an appealing avenue for populist candidates to circumvent the media establishment (a frequent target of populist ire) and reach voters directly (Conway, Kenski, \& Wang, 2013, p. 1597). It therefore stands to reason that those who turn to these new media sources should be more likely to support PRR candidates in primaries.

Golder's (2016, p. 490) invocation that future research should be at the intersection of supply and demand is apt, as both schools of thought are critical to explaining PRR success. The key point of intersection is with the source of information available to voters: the media-particularly in the form of new media that offer populists a direct route to their voters.

\subsection{New Media, Party Convergence, and the PRR Vote}

The explanatory factors highlighted above have one thing in common: none is complete without understanding how voters see the world. Voters are not always wellequipped to evaluate the nature or extent of phenomena cited by the PRR. As Norris and Inglehart (2019, p. 181) point out, "[t]he public may misperceive the extent of ethnic diversity, and of the crime rates and unemployment." If voters are rational actors whose political choices are based on how they perceive events, media diets matter.

In both Europe and the US, certain media outlets have had a special relationship with PRR figures. Ellinas (2010, pp. 8, 34) finds that the European far right's success is largely a function of media exposure. Such exposure is the product of a symbiotic relationship:

The political repertoire of the Far Right satisfies the thirst of the media for sensational, simplified, personalized, and controversial stories. Exaggerated references to violent crime and urban tension, which are typical ingredients of Far Right appeals, match the growing tendency of the media to dramatize news. The "simplism" that also characterizes Far Right appeals (Lipset and Raab, 1978) is in line with a media appetite for monocausal explanations and for the delivery of easy solutions to complex phenomena. (Ellinas, 2010, p. 34)

In the US, changes in technology and the regulatory environment have facilitated the rise of reactionary outlets that thrive on this "simplism" and controversy. Among other qualities, these "outrage" outlets are reactive, engaging, ideologically selective, and centered on personality (Berry \& Sobieraj, 2014, p. 14). Talk radio hosts stoke controversy to generate audience engagement, Fox News dominates cable, and right-wing websites flood the Internet with dubiously factual attack pieces.

Of course, not all media are equal. The growth of the competitive 24-hour news market in the 1990s, along 
with satellite radio and the Internet, changed the game for outrage media. New media outlets are appropriate venues for outrage content. These outlets make noor weak-claims to objectivity, and the Internet makes news more accessible than ever. A blog run out of a basement can draw millions of monthly visitors. The mode of dissemination also matters. New media, characterized by its embrace of new technology, along with "plurality, accessibility, and participation," (Fenton, 2010, p. 6), best exemplified by social media, should be more likely to mobilize support for PRR candidates, for several reasons.

The first key reason is the combination of purity testing and convergence rhetoric. According to Kitschelt and McGann (1995, pp. 17-25), convergence between the mainstream right and the mainstream left is a necessary condition for the radical right's success in Europe. In promoting themselves as an alternative to the mainstream left and right, the PRR often conflates them. As anti-establishment brands, PRR candidates are well-positioned to take advantage of disaffection with establishment parties. In Europe, distinct parties emerge. In the US, where the majoritarian political system freezes out third parties, I suggest that this competition should instead be found within Republican primaries. Instead of fringe parties accusing mainstream parties of collusion, American PRR candidates accuse mainstream Republicans of being insufficiently Republican, and attack the party establishment itself, as Donald Trump did in 2016. The conservative media indulges such controversy, and moderate members of the party caucus - those "insufficiently conservative" Republicans-can expect to be attacked as "Republicans in Name Only" (RINOs; Goldberg, 2013, p. 10). This leads to a first hypothesis:

H1: If a conservative voter believes that the mainstream liberal and conservative parties have "converged," that is, adopted similar positions on important issues, he or she is more likely to support a PRR candidate.

Leading up to 2016, making a case for party convergence would have been difficult. Polls have indicated that over time Americans have become more inclined to differentiate the parties (Lee, 2016, p. 140). The question, then, is how do voters come to believe that supporting an establishment Republican is essentially the same as supporting a Democrat?

I suggest that the answer aligns with the second reason that new media and the PRR are synergistic: The PRR's claims and proposed solutions are eye-catching, and are likely to be treated skeptically by the mainstream press. Exaggerations about crime, along with unconstitutional or poorly articulated policy proposals, may draw ridicule from trained journalists. But the same is not necessarily true of new media. Whereas legacy media have standards intended to prevent journalists from reporting misleading stories, social media feeds and partisan blogs are not beholden to traditional editorial standards. Once a story is released, editors have no control over the commentary readers attach as they share it with their personal networks, and those networks' insularity magnifies the message and shields audiences from rebuttal (Jamieson \& Capella, 2008, p. 76).

The melding of outrage media with social media provides a powerful platform for the PRR. Social media can support upstart candidacies because it allows ideas to permeate networks uncritically. Social media is also conducive to purity testing, in which we would expect PRR politicians to have a distinct advantage, given that most PRR candidates have never held elected office and so have never had to compromise. It therefore stands to reason that exposure to the sort of information that is likely to propagate in a social media environment reinforces support for PRR politicians among ideologically susceptible conservatives. In their discussion of the 2016 presidential election, Groshek and Koc-Michalska (2017, p. 1402) find that "loosening of gatekeeping certainly opened the doors to a mediated information environment that while diverse and expansive was also hostile and prone to misinformation that may well have reinforced citizens' pre-existing viewpoints." I therefore hypothesize that social media use should be related to support for the PRR:

H2: If a conservative voter is exposed to social media news, he or she is more likely to support a PRR candidate.

Because the theory outlined here should apply to the PRR beyond the presidency, I employ a state-level case study to evaluate these hypotheses.

\section{Case Study: The Arizona US Senate Primary, 2018}

After Donald Trump's 2016 victory, Republicanism became a contested concept. Trump's irreverent use of social media, his attacks on the establishment, and his embrace by American conservatism's Internet fringe created a new playbook for the fresh crop of PRR candidates who began competing in Republican primaries around the country.

The next round of primaries for federal office took place in summer 2018. While the general election decides who goes to Washington, the battle between conservative factions takes place at the primary stage. In the American majoritarian system, once the parties have selected candidates, voters essentially have a choice between the Republican and the Democrat, and many will default to their party's candidate out of loyalty, or as a strategic vote against the opposition (Mudde, 2017, p. 76). The primary is therefore a better venue for analysis of the PRR.

A suitable primary meets several conditions. First, it is for federal office, since many of the issues the PRR emphasizes are federal responsibilities. Second, there 
should be clear competition between the PRR and the Republican establishment. Third, it should have no incumbent, in order to better isolate the impact of explanatory variables on a PRR candidacy. Finally, a Senate election is preferable, because states cannot be gerrymandered, and because states are often larger and more diverse than districts.

\subsection{Background and Candidates}

On August 28, 2018, Arizona Republicans selected their nominee for the Senate seat vacated by Jeff Flake. Flake was a moderate Republican who decided to leave on account of what he saw as the erosion of traditional Republican values in the Trump era. Flake's withdrawal signaled that the party's radical wing had made his moderation politically untenable. In stepping down, Flake created a vacuum. Three major candidates contested the primary.

\subsubsection{Martha McSally: The Establishment Candidate}

Martha McSally is a military veteran elected to Congress in 2015. In her early career, McSally's views were moderate: She supported pro-life positions on abortion, traditional marriage, and immigration reform with a path to legalization (Parker, 2014). Dubbed by Politico "the House GOP's top recruit," McSally also supported a bipartisan equal pay bill and refused to endorse Tea Party principles (Isenstadt, 2014). McSally's candidacy represented progress for the establishment GOP, and their female recruitment project cited her primary victory as a success (Henderson \& Kucinich, 2014).

In the Trump era, McSally has been forced to balance criticism of the party's leader with maintaining the base's support. When Trump attacked McCain for being captured in Vietnam, McSally was the only member of the Arizona delegation to speak out (Nowicki, 2015). Even after Trump secured the nomination, McSally declined to endorse him (Hansen, 2016). Of course, Trump won Arizona, and has remained popular with Republicans. McSally made overtures to Trump's base throughout the 2018 campaign, highlighting her interactions with the President and hinting at the existence of a working relationship (Wingett Sanchez, 2018). Despite these efforts, McSally did not credibly represent the PRR in 2018, and was instead a target of convergence rhetoric from her opponents in the primary (Sullivan, 2018). McSally also ran a much more traditional campaign: Even after her appointment to the Senate, she still has fewer "likes" on Facebook and followers on Twitter than Ward or Arpaio, and she attracted far more establishment support.

\subsubsection{Joe Arpaio: The Anti-Immigrant Crusader}

Before his Senate campaign, Joe Arpaio served as Republican elected Sheriff of Maricopa County from 1993 until 2017, where he became notorious for housing prisoners in tents, reinstituting chain gangs, and cut- ting meal costs (Arpaio \& Sherman, 2008, pp. 96-97, 213). He also aggressively pursued an anti-illegal immigration agenda.

As Sheriff, Arpaio denounced the dangers of illegal immigration from Mexico. He called for a "war" on illegal immigration, citing threats to culture and sovereignty. He asks his readers, "[a]re we prepared to give up our sovereignty? Are we willing to give up our national identity?" (Arpaio \& Sherman, 2008, p. 244). Though he often frames it as law enforcement, Arpaio is making a nativist cultural argument familiar to observers of the European right.

Arpaio's office consistently violated Latino citizens' civil rights by illegally detaining them as part of its war on illegal immigration. When a judge issued an injunction to halt this practice, Arpaio ignored it, and was convicted of criminal contempt (Pérez-Peña, 2017). Trump later pardoned the Sheriff, leading Breitbart to run the headline, "Trump Defends Arpaio Pardon as GOP Establishment Joins the Left" (Mason, 2017). These events highlight fault lines in the post-Trump conservative movement, and place Arpaio in the anti-establishment camp.

For Arpaio, the 2018 campaign proceeded familiarly. On his signature issue he supported hardline policies, suggesting that foreigners brought to the country illegally as children should be deported, and that the military should be deployed to Mexico to combat drug smuggling (Romero, 2018). In line with the convergence theme, Arpaio said of McSally, "she sounds like a Democrat" (Sullivan, 2018). When it came to the party's right fringe, however, Arpaio had competition.

\subsubsection{Kelli Ward: The Outsider}

Kelli Ward burst onto the national stage in 2016 with an unsuccessful primary challenge against John McCain. Shortly after her defeat, she announced that she would challenge Flake. Ward, a former state legislator, became a PRR darling for her anti-establishment politics. By 2018, Ward had established herself as "the perfect spokesperson for the Trump wing of the GOP" (Posner, 2017). Ward also received endorsements from radical right figures. Representative Paul Gosar, known for his radical positions and relationship with the European right, called McSally an "establishment patsy," and endorsed Ward (Garcia, 2018), as did Sebastien Gorka, a former Trump deputy with European far right ties (Farzan, 2018).

This contest attracted the Republican establishment. The Senate Majority Leader's allies poured money into the race, bolstering McSally as an immigration hardliner, and drawing fire from the Ward campaign, which attacked McSally's record on Trump, the border wall, and "dozens of votes for amnesty" (Arkin, 2018). Combat between the Republican establishment and the PRR flared throughout the summer. Ward attacked McSally's conservatism and attempted to tie her to the left, by alleging that McSally had voted for amnesty "11 times" in a misleading radio ad (Athey, 2018). Ward immersed herself 
in anti-establishment convergence rhetoric, and in a further step away from the establishment, she attempted to leverage the conservative Internet media ecosystem.

Ward campaigned with far right Internet personality Mike Cernovich, whom The Washington Post called, "[her] newly minted campaign surrogate" (Selk, 2018). Breitbart editor and Trump strategist Steve Bannon participated in Ward's campaign launch (Nowicki, 2017), and until September 2017, several senior campaign aides were former Breitbart reporters (Moore, 2017). These Breitbart connections are especially important in evaluating the theory presented here, as Faris et al. (2017, pp. 11-13) find that Breitbart formed "the nexus of conservative media" in 2015-2016, and was the most popular source for social media sharing on the right during the 2016 election. Ward was also among a group of insurgent Republicans who benefited from websites masquerading as legitimate news sites that produced antiestablishment content and endorsed candidates under the guise of independent journalism (Schwartz, 2018).

\section{Methodology}

The research question posed here is "Does use of social media for news drive support for the PRR in Republican primaries?" To test the hypotheses that perceptions of convergence and use of social media drive support for PRR candidates, I employed Qualtrics to distribute an online survey to 1052 self-identified Arizona Republicans in the week leading up to the primary in August 2018. Qualtrics (2014, p. 4) offers the following disclaimer: "Qualtrics panel partners randomly select respondents for surveys where respondents are highly likely to qualify....Each sample from the panel base is proportioned to the general population and then randomized before the survey is deployed."

\subsection{Variables}

To capture attitudes about immigration, I used several American National Election Survey (ANES) measures, including one that asks how worried respondents are about illegal immigration, and one that asks if immigrants are "generally good for America's economy." To capture economic anxiety, I asked voters how worried they were about employment status using another ANES measure. To measure authoritarian values, I included four standard ANES child-rearing questions and created an index (see also MacWilliams, 2016). To test convergence, I asked voters if there were any important differences between the Republican establishment and the Democratic Party. I also asked about perceptions of corruption and concern about RINOs to gauge disaffection with the party. To measure exposure to social media, I asked voters where they get their news.

The dependent variable (DV) is the answer to the question "if the 2018 Arizona Republican Senate Primary election were held today, which of the candidates would you vote for?" Support for each candidate is the DV for each model reported in Table 1.

\subsection{Method}

I use logistic regression because the DV is dichotomous. Logistic regression coefficients are difficult to interpret because they represent log odds, so I have reported the results as odds ratios (ORs). The OR "describes how much more likely an outcome is to occur in one group as compared to another group" (Braver, Tboemmes, \& Moser, 2010 , p. 957), representing the relative odds of two related outcomes occurring. For example, in Table 1, the OR for the variable "Race (white)" in the McSally model is the odds that a McSally supporter is white divided by the odds that he/she is not. This OR is less than one, indicating that a McSally supporter is 0.75 times as likely as a non-McSally voter to be white (though this is not significant). For ordinal independent variables, the OR increases or decreases exponentially, so for each additional year of age, a voter is 1.02 times as likely to vote for McSally (Braver et al., 2010, p. 958).

\section{Results}

The results, displayed below in Table 1, largely support the hypotheses proposed above. $\mathrm{H} 1$ holds that PRR voters should be more likely to perceive convergence between the parties, and this is the case. As expected, McSally voters are less likely to perceive corruption to be widespread, and while the other two variables of interest (party similarity and RINOs are a detriment) are not significant, they are directionally correct. Ward's voters are nearly twice as likely to agree that there are no differences between the Republican establishment and the Democratic Party, and they are substantially more likely to agree that RINOs are a detriment to the Republican Party. $\mathrm{H} 1$ does little to explain Arpaio support, however.

$\mathrm{H} 2$ holds that PRR voters should be more likely to get their news from social media sources. The data support $\mathrm{H} 2$ in the McSally and Ward cases. McSally's supporters are roughly half as likely to use social media for news, and nearly twice as likely to turn to Fox News. Ward's supporters are more likely to turn to social media for news, as expected, while Arpaio's supporters are less likely to watch Fox or listen to talk radio. Neither fear of job loss nor authoritarian attitudes are significant, though Arpaio's supporters are substantially more likely to perceive immigrants as bad for the economy, as would be expected according to economic demand side theories. Finally, McSally's supporters are slightly older and Ward's slightly younger, while Arpaio's supporters have lower levels of education and are less conservative.

\section{Analysis}

$\mathrm{H} 1$ predicts that PRR voters should be likely to perceive convergence between the parties. This is borne out in 
Table 1. Factors that influence support for 2018 Arizona Senate candidates among self-identified Republican likely voters.

\begin{tabular}{|c|c|c|c|}
\hline Independent variable & McSally support & Ward support & Arpaio support \\
\hline No differences between Rep./Dem. establishment & 0.76 & $1.79 *$ & 0.96 \\
\hline Perception of corruption (1-4) & $0.77^{*}$ & 1.26 & 1.10 \\
\hline RINOs are a detriment (1-5 [strongly agree]) & 0.89 & $1.41 * * *$ & 0.91 \\
\hline Social media news consumer & $0.60 * *$ & $1.79 *$ & 1.24 \\
\hline Talk radio news consumer & 1.12 & 1.16 & $0.59 *$ \\
\hline Fox News viewer & $1.71 * *$ & 0.79 & $0.63 *$ \\
\hline Fear of job loss (1-5 [extremely worried]) & 1.03 & 1.02 & 0.94 \\
\hline Authoritarianism (0-4) & 1.00 & 0.95 & 1.19 \\
\hline Immigrants good for economy (1-5 [strongly disagree]) & $0.84 *$ & 0.93 & $1.46 * * *$ \\
\hline Education (1-5 [highest]) & 1.10 & 1.13 & $0.74 * *$ \\
\hline Income (1-5 [highest]) & 1.11 & 1.04 & 0.81 \\
\hline Age (years) & $1.02 * *$ & $0.98 *$ & 0.98 \\
\hline Ideology (1 [extremely liberal]-7 [extremely conservative]) & 1.05 & 1.21 & $0.83 *$ \\
\hline Race (white) & 0.75 & 2.29 & 0.75 \\
\hline Constant & 1.24 & $0.01 * * *$ & 3.67 \\
\hline$n$ count & 739 & 739 & 739 \\
\hline Pseudo r-squared & 0.07 & 0.07 & 0.11 \\
\hline
\end{tabular}

Note: ${ }^{*}=p<.05, * *=p<.01, * * *=p<.001$.

Ward's case, but not in Arpaio's case. Voters who believe that establishment Republicans and the Democratic Party are indistinguishable are nearly twice as likely to support Ward. It appears that efforts to paint McSally as an establishment patsy were successful, but that antiestablishment voters do not view Arpaio, an experienced politician, as a suitable outlet for their disaffection. The fact that Ward's voters are also more likely to identify "fake" Republicans ("RINOs") as a detriment indicates that, for many Republicans, mainstream offerings are impure. McSally's voters, perhaps tired of their candidate drawing criticism as insufficiently Republican, do not perceive RINOs to be a threat. Corruption perceptions among likely voters tell an interesting story as well. Populists, including Trump, paint the world as full of corruption. They pledge to "drain the swamp" and make government work for the people again, claiming that both parties have contributed to the status quo. I therefore expect that PRR supporters should believe corruption to be more problematic. Although this variable is not significant in either the Ward or Arpaio models, McSally's voters are less likely to perceive corruption-providing some corroboration for the hypothesis.

The supply side literature suggests that the PRR succeeds where convergence between mainstream parties creates a favorable opportunity structure (Kitschelt \& McGann, 1995, p. 17). The analysis here indicates that voters who believe in party convergence do, in fact, disproportionately support Ward, a PRR candidate. This finding provides evidence that a supply side explanation derived theoretically from European party systems and patterns of communication (convergence rhetoric) can travel to American party primaries, where a firstpast-the-post electoral system makes multi-party competition untenable.

There are, however, some caveats that limit the scope of this finding. While convergence explanations are typically applied at the party system level (e.g., Katz \& Mair, 2009), here I operationalize convergence at the level of individual perception. I have done so for two reasons. First, the DV examined is support for individual candidates, not organized parties. Even the most ephemeral parties typically outlast individual candidacies. Second, voters' perceptions may not align with reality. I do not claim here that actual party convergence explains PRR success, but rather that when a voter believes that the parties have converged, the PRR becomes a rational selection. The best way to operationalize perception is at the individual level.

Endogeneity limits my ability to make causal inferences about convergence. It is not possible to determine if anti-establishment attitudes caused Ward support or vice versa based on this cross-sectional analysis. That said, the fact that those Republican primary voters that support a PRR candidate also believe that the Republican establishment is indistinguishable from the Democrats sheds light on how the PRR can successfully mobilize within an existing conservative party.

The second part of the story concerns the reason for these beliefs. $\mathrm{H} 2$ holds that PRR voters should be more likely to get their news from social media, at least in part because social media offer an environment for vot- 
ers to consume and share belief-affirming information. $\mathrm{H} 2$ is also borne out in the Ward case, but, again, not for Arpaio. While McSally supporters are more likely to watch Fox News, Ward supporters are nearly twice as likely to use social media for news. This suggests that the characteristics of social media news are appealing to PRR voters, and may therefore benefit PRR candidacies. In line with previous research (Groshek \& Koc-Michalska, 2017), consumption of social media news does appear to correlate with support for populists in primaries. Ward's willingness to embrace new media, conspiracy theories, convergence rhetoric/purity testing, and outlandish claims drew criticism from the mainstream press, but endeared her to the Internet fringe, who disproportionately turned out for her in the primary at Arpaio's expense.

Surprisingly, neither Fox nor talk radio boost support for either PRR candidate, perhaps because Trump did not endorse any candidate after Flake dropped out, or because national conservative hosts were less likely to cover a state's primary competition. It is also possible that, although conservative outlets like Fox and major talk radio hosts (e.g., Rush Limbaugh and Sean Hannity) often position themselves as counterweights to the liberal establishment, committed anti-establishment primary voters may consider those outlets part of the establishment themselves. If anti-establishment voters consider traditional conservative media to be part of the establishment, social media would be even more attractive for these voters-especially in light of characteristics such as the ability for candidates to speak directly to voters on platforms like Twitter and Facebook, the "loosening of gatekeeping" (Groshek \& Koc-Michalska, 2017 , p. 1402), and the potential for stories to spread quickly without any official endorsement. Social media's grassroots, viral nature is especially appealing to the PRR. While this cross-sectional analysis cannot establish causality, the evidence presented strongly suggests that when voters are exposed to the (relatively) gatekeeperfree world of social media news, PRR talking points become more prominent and more compelling.

\subsection{Sheriff Joe and the PRR}

Arpaio's voters have less in common with Ward's voters than expected. While both groups trend younger, Arpaio's voters appear to be driven by concerns about immigration. In Europe, PRR parties often appeal to both anti-establishment and anti-immigration voters. The Arizona Senate primary included two candidates vying for largely the same base, each appearing to attract only part of it. Arpaio, because of his tenure as a Republican official with a national profile built on crime and immigration, is the natural choice for committed Republicans who prioritize those issues. This would explain why Arpaio's supporters are less likely to agree that immigrants are good for the economy. The fact that Arpaio's supporters are also less educated offers a partial explanation for the economic threat of immigration they perceive, as expected by some of the demand side literature (e.g., Jackman \& Volpert, 1996).

Arpaio's voters are less likely to identify as "very conservative." Moderate Republicans who feel economic pressure from immigration might find the scorched earth, conspiratorial politics of the PRR appealing, but prioritize effective immigration policy over "draining the swamp." It appears that Arpaio appealed to antiimmigrant Republicans, while Ward attracted the antiestablishment camp. The PRR coalition was split: Arpaio successfully drew the nativists, while Ward appealed to the populists.

It is unclear, however, how much of Arpaio's success is due to his outsized public profile. As a longtime local politician with national name recognition, Arpaio may have gained some of the advantages of incumbency without holding the desired office. For example, his name recognition may have led the electorate to perceive him as more viable (Kam \& Zechmeister, 2013, p. 983). However, I do not believe that Arpaio's name recognition is sufficient to explain the results for two reasons. First, leading up to the primary, much of the news coverage about Arpaio concerned either the pardon he received from Trump or commentary on his "irrelevance" (Romero, 2018). Second, while name recognition is powerful in local elections contested by relative unknowns, the 2018 Arizona Senate primary was a highprofile race. All three candidates had claims to relevance. Ward and Arpaio both drew Donald Trump's attention in 2016, and McSally served in Congress. The primary received national media coverage, and the results had potential to carry national implications (i.e., the Senate may have flipped from Republican to Democratic control). Voter turnout was also record-breaking: More than 670,000 voters participated in the Republican primary (Daniels, 2018).

\section{Conclusion}

This analysis offers evidence that theoretical expectations about party convergence and social media use can explain some PRR success in the US. In Arizona, among Republicans, Kelli Ward's supporters are more likely to see the Republican establishment as functionally Democratic and to report accessing social media news. Joe Arpaio's supporters, on the other hand, do not share these characteristics: They are more likely to perceive immigration as economically disadvantageous, and to have lower levels of education. These findings indicate that the PRR coalition comprises both anti-immigrant and anti-establishment supporters, and that the two groups are not coterminous. The PRR encompassing two distinct camps is consistent with the theory that populism is a thin-centered ideology (or "toolkit," or style) that is not inherently tied to other left or right ideologies like nativism (Mudde, 2007, p. 23; Ylä-Anttila, 2017, p. 8). The results also support the supply side idea that there is a symbiotic relationship between social media and the 
PRR. Though this evidence is not definitively causal, it offers a compelling circumstantial case for social media's power.

Furthermore, these results suggest that transitioning from experienced party politician to insurgent is difficult, and that while long experience in office may establish credibility on issues, it is detrimental in attracting antiestablishment support.

The theory presented here is drawn from European literature on both the supply side and the demand side, with a specific focus on the part convergence and new media play in facilitating PRR success. The American party system produces different constraints than many of its European counterparts, forcing PRR competition into the intra-party arena. Nevertheless, the evidence demonstrates that, when properly contextualized, similar phenomena facilitate support for the PRR on both sides of the Atlantic.

Future research should expand the scope of the analysis to include independents. Participants in the examined survey self-identified as Republicans, but nonRepublicans can and do vote in primaries. PRR candidates like to position themselves as alternatives to leftright politics. Self-identified independents could therefore have an important role to play in explaining PRR success in the US. This is a promising area for future inquiry.

\section{Acknowledgments}

I acknowledge the helpful comments provided by Cristine de Clercy and Peter Ferguson, and their continued support for my research. I am grateful to Fred Chagnon, Kimberly McKay, and Leanna Seaman for their assistance in recovering a lost draft of this article. Finally, I thank Derek Shank for his thorough editing job.

\section{Conflict of Interests}

The author declares no conflict of interests.

\section{Supplementary Material}

Supplementary material for this article is available online in the format provided by the author (unedited).

\section{References}

Arkin, J. (2018, June 15). McConnell allies jump into critical Senate primary. Politico. Retrieved from https://www.politico.com/story/2018/06/15/ mcconnell-allies-martha-mcsally-senate-primaryarizona-648029

Arpaio, J., \& Sherman, L. (2008). Joe's law: America's toughest sheriff takes on illegal immigration, drugs, and everything else that threatens America. New York, NY: AMACOM.

Art, D. (2011). Inside the radical right: The development of anti-immigrant parties in Western Europe. Cam- bridge: Cambridge University Press.

Athey, P. (2018, August 10). Kelli Ward claims Martha McSally has supported amnesty 11 times. Is she right? The Arizona Republic. Retrieved from https:// eu.azcentral.com/story/news/politics/fact-check/ 2018/08/10/fact-check-does-martha-mcsallysupport-amnesty-kelli-ward-claims/836310002

Berry, J. M., \& Sobieraj, S. (2014). The outrage industry: Political opinion media and the new incivility. New York, NY: Oxford University Press.

Betz, H. (1993). The new politics of resentment: Radical right wing populist parties in Western Europe. Comparative Politics, 25(4), 413-427.

Boomgaarden, H. G., \& Vliegenthart, R. (2007). Explaining the rise of anti-immigrant parties: The role of news media content. Electoral Studies, 26(2), 404-417.

Braver, S. L., Tboemmes, F., \& Moser, S. E. (2010). Odds ratio. In N. J. Salkind (Ed.), Encyclopedia of research design (pp. 957-959). London: SAGE.

Bustikova, L. (2014). Revenge of the radical right. Comparative Political Studies, 47(12), 1738-1765.

Coffé, H., Heyndels, B., \& Vermier, J. (2007). Fertile grounds for extreme right-wing parties: Explaining the Vlaams Blok's electoral success. Electoral Studies, 26(1), 142-155.

Conway, B. A., Kenski, K., \& Wang, D. (2013). Twitter use by presidential primary candidates during the 2012 campaign. American Behavioral Scientist, 57(11), 1596-1610.

Daniels, M. (2018, September 7). Arizona voters break record for primary turnout. Associated Press. Retrieved from https://apnews.com/a11f2a61775c 4490976685df18f3a842

de Lange, S. L. (2007). A new winning formula? The programmatic appeal of the radical right. Party Politics, 13(4), 411-435.

DeClair, E. G. (1999). Politics on the fringe: The people, policies, and organization of the French National Front. Durham, NC: Duke University Press.

Ellinas, A. A. (2010). The media and the far right in Western Europe: Playing the nationalist card. Cambridge: Cambridge University Press.

Ellinas, A. A. (2013). The rise of Golden Dawn: The new face of the far right in Greece. South European Society and Politics, 18(4), 543-565.

Faris, R. M., Roberts, H., Etling, B., Bourassa, N., Zickerman, E., \& Benkler, Y. (2017). Partisanship, propaganda, and disinformation: Online media and the 2016 U.S. presidential election. Cambridge, MA: Berkman Klein Center for Internet \& Society, Harvard University.

Farzan, A. N. (2018, March 30). Making America safe again: Sebastian Gorka stumps for Kelli Ward. Phoenix New Times. Retrieved from https://www. phoenixnewtimes.com/news/sebastian-gorkacampaigns-for-kelli-ward-in-scottsdale-10283174

Fenton, F. (2010). Drowning or waving? New media, jour- 
nalism, and democracy. In F. Fenton (Ed.), New media, old news: Journalism \& democracy in the digital age (pp. 3-10). London: SAGE.

Garcia, E. (2018, July 18). Gosar endorses Ward over McSally in Arizona Senate race. Roll Call. Retrieved from https://www.rollcall.com/2018/07/18/gosarendorses-ward-over-mcsally-in-arizona-senaterace

Goldberg, J. (2013). Who's the RINO? National Review, 65(22), 10.

Golder, M. (2016). Far right parties in Europe. Annual Review of Political Science, 19(1), 477-497.

Groshek, J., \& Koc-Michalska, K. (2017). Helping populism win? Social media use, filter bubbles, and support for populist presidential candidates in the 2016 US presidential election. Information, Communication, \& Society, 20(9), 1389-1407.

Gunn, E. (2017). Twitter as arena for the authentic outsider: Exploring the social media campaigns of Trump and Clinton in the 2016 US presidential election. European Journal of Communication, 32(1), 50-61.

Hansen, R. J. (2016, October 9). Paul Babeu, Martha McSally struggle to respond to Donald Trump fallout. The Arizona Republic. Retrieved from https://eu. azcentral.com/story/news/politics/elections/2016/ 10/09/paul-babeu-martha-mcsally-strugglerespond-donald-trump-fallout/91805874

Harteveld, E. (2016). Winning the 'losers' but losing the 'winners'? The electoral consequences of the radical right moving to the economic left. Electoral Studies, 44, 225-234.

Henderson, N., \& Kucinich, J. (2014, March 17). GOP sees progress, more work on gender gap. The Washington Post. Retrieved from https://www. washingtonpost.com/blogs/she-the-people/wp/ 2014/03/17/gop-sees-progress-more-work-ongender-gap

Imerzeel, T., \& Pickup, M. (2015). Populist radical right parties mobilizing 'the people'? The role of populist radical right success in voter turnout. Electoral Studies, 40, 347-360.

Isenstadt, A. (2014, June 9). The House GOP's top recruit. Politico. Retrieved from https://www.politico.com/ story/2014/06/martha-mcsally-house-republicans107628

Jackman, R. W., \& Volpert, K. (1996). Conditions favouring parties of the extreme right in Western Europe. British Journal of Political Science, 26(4), 501-521.

Jamieson, K. H., \& Capella, J. N. (2008). Echo chamber: Rush Limbaugh and the conservative media establishment. New York, NY: Oxford University Press.

Kam, C. D., \& Zechmeister, E. J. (2013). Name recognition and candidate support. American Journal of Political Science, 57(4), 971-986.

Karl, P. (2017). Hungary's radical right 2.0. Nationalities Papers, 45(3), 345-355.

Katz, R. S., \& Mair, P. (2009). The cartel party thesis: A restatement. Perspectives on Politics, 7(4), 753-766.
Kitschelt, H., \& McGann, A. J. (1995). The radical right in Western Europe: A comparative analysis. Ann Arbor, MI: University of Michigan Press.

Knigge, P. (1998). The ecological correlates of right-wing extremism in Western Europe. European Journal of Political Research, 34(2), 249-279.

Knuckey, J., \& Hassan, K. (2019). Authoritarianism and support for Trump in the 2016 presidential election. The Social Science Journal. Advance online publication. https://doi.org/10.1016/j.soscij.2019.06.008

Lee, F. E. (2016). Insecure majorities: Congress and the perpetual campaign. Chicago, IL: University of Chicago Press.

Lubbers, M., \& Scheepers, P. (2001). Explaining the trend in extreme right-wing voting: Germany 1989-1998. European Sociological Review, 17(4), 431-449.

MacWilliams, M. C. (2016). Who decides when the party doesn't? Authoritarian voters and the rise of Donald Trump. PS: Political Science and Politics, 49(4), 716-721.

Mason, I. (2017, August 28). Trump defends Arpaio Pardon as GOP establishment joins the left. Breitbart News. Retrieved from https://www.breitbart.com/ politics/2017/08/28/trump-defends-arpaio-pardonas-gop-establishment-joins-the-left

Moore, L. (2017, October 17). Bannon rips 'globalist elite' at Kelli Ward's Senate campaign fundraiser. Phoenix New Times. Retrieved from https://www. phoenixnewtimes.com/news/kelli-wards-shadysenate-kickoff-9791084

Mudde, C. (2007). Populist radical right parties in Europe. Cambridge: Cambridge University Press.

Mudde, C. (2017). The far right in America. New York, NY: Routledge.

Mudde, C. (2019). The far right today. Cambridge: Polity.

Muis, J., \& Scholte, M. (2013). How to find the 'winning formula'? Conducting simulation experiments to grasp the tactical moves and fortunes of populist radical right parties. Acta Politica, 48(1), 22-46.

Norris, P., \& Inglehart, R. (2019). Cultural backlash: Trump, Brexit, and authoritarian populism. New York, NY: Cambridge University Press.

Nowicki, D. (2015, July 24). Arizona GOP congressmen mum on Donald Trump slam of John McCain. The Arizona Republic. Retrieved from https://eu.azcentral. com/story/news/politics/azdc/2015/07/24/arizonagop-congressmen-mum-donald-trump-john-mccainmatt-salmon-martha-mcsally/30644967

Nowicki, D. (2017, October 17). Bannon endorses Ward, signaling Trump supporters have settled on a challenger to Flake. The Arizona Republic. Retrieved from https://eu.azcentral.com/story/news/politics/ elections/2017/10/17/steve-bannon-endorsearedonald-trump-supporters-settling-kelli-ward-theirpick-against-sen-jeff-flak/769872001

Parker, A. (2014, February 25). After career of firsts in Air Force, G.O.P. challenger has a new mission. The New York Times. Retrieved from https://www.nytimes. 
com/2014/02/26/us/politics/after-career-of-firstsin-air-force-gop-challenger-martha-mcsally-has-anew-mission.html

Peabody, B. G. (2018). The curious incident of Trump and the courts: Interbranch deference in an age of populism. British Journal of American Legal Studies, 7(2), 237-256.

Pérez-Peña, R. (2017, July 31). Former Arizona Sheriff Joe Arpaio is convicted of criminal contempt. The New York Times. Retrieved from https://www. nytimes.com/2017/07/31/us/sheriff-joe-arpaioconvicted-arizona.html

Plattner, M. F. (2010). Populism, pluralism, and liberal democracy. Journal of Democracy, 21(1), 81-92.

Posner, S. (2017, August 22). Kelli Ward is the perfect spokesperson for the Trump wing of the GOP. The Washington Post. Retrieved from https://www. washingtonpost.com/blogs/plum-line/wp/2017/08/ 22/kelli-ward-is-the-perfect-spokesperson-for-thetrump-wing-of-the-gop

Qualtrics. (2014). ESOMAR 28: 28 questions to help research buyers of online samples [Brochure]. Provo: Qualtrics.

Romero, S. (2018, August 27). In Arizona Primary, Joe Arpaio is making his last stand. The New York Times. Retrieved from https://www.nytimes.com/2018/08/ 27/us/arpaio-arizona-senate.html

Schwartz, J. (2018, February 14). Kelli Ward touts endorsement from fake-news site. Politico. Retrieved from https://www.politico.com/story/2018/02/14/ arizona-senate-kelli-ward-fake-news-407281

Selk, A. (2018, August 25). Mike Cernovich steps into the U.S. Senate race in Arizona. A 'gonzo thing,' he says. The Washington Post. Retrieved from https:// www.washingtonpost.com/politics/mike-cernovichsteps-into-the-us-senate-race-in-arizona-a-gonzothing-he-says/2018/08/25/d0fe9ece-a7bd-11e8a656-943eefab5daf_story.html

Stockemer, D., \& Barisione, M. (2017). The 'new' discourse of the Front National under Marine Le Pen: A slight change with a big impact. European Journal of Communication, 32(1), 100-115.

Sullivan, S. (2018, August 23). Establishment Republicans grow optimistic about winning bruising Arizona primary. The Washington Post. Retrieved from https://www.washingtonpost.com/ powerpost/establishment-republicans-growoptimistic-about-winning-bruising-arizonaprimary/2018/08/23/bbc444a0-a4bb-11e8-8fac12e98c13528d_story.html

Wingett Sanchez, Y. (2018, July 24). In Arizona's Senate race, Martha McSally cozies up to Donald Trump. The Arizona Republic. Retrieved from https:// eu.azcentral.com/story/news/politics/arizona/2018/ $07 / 24 /$ martha-mcsally-cozies-up-donald-trumparizonas-senate-race/798813002

Ylä-Anttila, T. (2017). The populist toolkit: Finnish populism in action 2007-2016 (Unpublished Doctoral dissertation). University of Helsinki, Helsinki, Finland.

\section{About the Author}

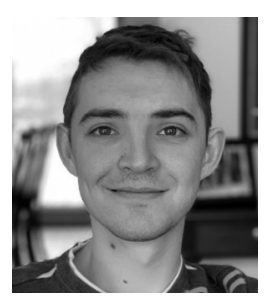

Jeremy C. Roberts is a PhD Candidate in the Department of Political Science at the University of Western Ontario. His research interests include the history and rise of the radical right in the US, American presidential politics, and the relationship between the study of the European right and the American right. 